\title{
Universiteit
}

Leiden

The Netherlands

\section{Remedies for Victims of Violations of International Humanitarian Law}

Zegveld, L.

\section{Citation}

Zegveld, L. (2003). Remedies for Victims of Violations of

International Humanitarian Law. International Review Of The Red Cross, 85(851), 499-528. Retrieved from https://hdl.handle.net/1887/14022

Version: $\quad$ Not Applicable (or Unknown)

License: $\quad$ Leiden University Non-exclusive license

Downloaded from: $\quad$ https://hdl.handle.net/1887/14022

Note: To cite this publication please use the final published version (if applicable). 


\title{
Remedies for victims of violations of international humanitarian law
}

\author{
LIESBETH ZegVELD*
}

International humanitarian law ("IHL") has never been confined to the level of relations between States. ${ }^{1}$ On the contrary, the initiators of the nineteenth century conventions already believed that human persons had inviolable rights even during armed conflicts. ${ }^{2}$ However, recognition of rights is one thing, the right to claim those rights is another. So far, States have been reluctant to entitle, explicitly and in general, victims of violations of international humanitarian law to claim reparation. As humanitarian law treaties do not expressly envisage causes of action for victims in national or international law, they are hardly able to exercise their rights.

On this point international humanitarian law sharply contrasts with tendencies in international law. In spite of the gap in the International Law Commission's Articles on State Responsibility, which were finally adopted in $2001^{3}$ but fail to mention rights of individuals in the regime of secondary rights, ${ }^{4}$ it is generally known that human rights treaties provide a remedy, both substantive and procedural, for individuals suffering injury from unlawful conduct by State authorities. For example, Article 13 of the European Convention on Human Rights stipulates that individuals whose rights as set forth in that Convention are violated shall have "an effective remedy before a national authority". And Article 50 of the same Convention mandates the European Court of Human Rights to afford just satisfaction to victims. Human rights treaties also provide for specific provisions on compensation, for example to victims of unlawful arrest or detention. ${ }^{5}$ Most recently, the Rome Statute of the International Criminal Court ${ }^{6}$ authorizes the Court to determine any damage, loss or injury to victims and order reparations to them.

* Liesbeth Zegveld, Ph.D. practises as an international lawyer in Amsterdam, the Netherlands. She would like to thank Frits Kalshoven for his useful comments and Gijs Kuijper for his assistance in preparing this article. 
While the punishment of individuals for war crimes has received much greater attention over the past decade, shifting some inter-State aspects of IHL to individual criminal responsibility, the position of the victims of these crimes has not been equally addressed. Their rights and interests have largely been overlooked. Yet redress and reparation for victims of violations of IHL is an imperative demand of justice. The relevance of rights under IHL is questionable if victims have no legal capacity to enforce their rights, before either a national or an international tribunal, once they claim to have become a victim. As pointed out by Lord Denning: "a right without a remedy is no right at all"?

The United Nations Commission on Human Rights has recognized the interests of victims of IHL violations. The "Basic Principles and Guidelines on the Right to a Remedy and Reparations for Victims of Violations of International Human Rights and Humanitarian Law" (hereinafter "UN Principles on the Right to a Remedy"), adopted by the United Nations Commission on Human Rights at its 56 th session in $2000,{ }^{8}$ aim to provide

1 As one commentator put it, the purpose of international humanitarian law is to go "beyond the interstate levels and [to reach] for the level of the real (or ultimate) beneficiaries of humanitarian protection, i.e. individuals and groups of individuals", G. Abi-Saab, "The specificities of humanitarian law”, in C. Swinarski (ed.), Studies and Essays of International Humanitarian Law and Red Cross Principles in Honour of Jean Pictet, ICRC, Geneva/The Hague, 1984, p. 269; similarly, T. Meron, “The humanization of humanitarian law”, American Journal of International Law, Vol. 94, 2000, pp. 239-278.

2 J. Pictet (ed.), Commentary: IV Geneva Convention relative to the Protection of Civilian Persons in Time of War, ICRC, Geneva, 1958, reprinted 1994, p. 77.

3 International Law Commission Articles on Responsibility of States for Internationally Wrongful Acts, adopted on second reading by the International Law Commission ("ILC") at its 53rd Session (UN Doc. A/CN.4/L.569, 9 August 2001) and by the General Assembly on 12 December 2001, Res. 56/83, text available at <http://www.law.cam.ac.uk/rcil/ILCSR/Statresp.htm>.

4 Art. 33(2) of these Articles, Ibid., contains a saving clause, stipulating that the Articles are "without prejudice to any right, arising from the international responsibility of a State, which may accrue directly to any person or entity other than a State". This provision underlines that the Articles do not deal with the possibility of the invocation of responsibility by persons or entities other than States; it merely recognizes the possibility that individuals may be entitled to claim reparation for violations of primary norms of international humanitarian law by States. See J. Crawford, The International Law Commission's Articles on State Responsibility, Cambridge University Press, Cambridge, 2002, p. 210.

5 See for example Art. 5(9) of the International Covenant of Civil and Political Rights of 1969.

6 Of 17 July 1998, UN doc. A/CONF.183/9, Art. 75.

7 Lord Denning in Gouriet v. Union of Post Office Workers, AC, 1978, p. 435, cited in R. Higgins, "The role of domestic courts in the enforcement of international human rights: The United Kingdom”, in B. Conforti and F. Franciani (eds.), Enforcing International Human Rights in Domestic Courts, Martinus Nijhoff Publishers, The Hague, 1997 , p. 38.

8 E/CN.4/2000/62, 18 January 2000. Pursuant to its resolution 1989/13, the Sub-Commission on Prevention of Discrimination and Protection of Minorities entrusted Mr. Theo van Boven with the task of 
victims of violations of human rights and IHL with a right to a remedy. The content of this right includes access to justice, reparation for harm suffered and access to factual information concerning the violations. ${ }^{9}$ It distinguishes between five forms of reparation: restitution, compensation, rehabilitation, satisfaction, and guarantees of non-repetition. ${ }^{10}$

These UN Principles have been corroborated by several other initiatives. In 1998, in the Hague Agenda for Peace and Justice, the Hague Appeal for Peace and Justice for the 21st Century defined implementation of IHL as its overriding theme and made the following recommendation: "The Hague Appeal will advocate changes in the development and implementation of the laws in both these fields [IHL and human rights law], in order to close critical gaps in protection and to harmonize these vital areas in international law". ${ }^{11}$ In 2003, building on these initiatives, the Amsterdam Centre for International Law ("ACIL") of the University of Amsterdam and the Netherlands Institute of Human Rights of the University of Utrecht organized two expert meetings to discuss the need for and feasibility of new procedures that provide remedies for victims of violations of IHL. The meeting in May 2003 discussed whether existing international mechanisms can provide victims of violations of international humanitarian law with a remedy and provide reparation. On the basis of its findings, the follow-up meeting in October 2003 will examine different options for filling gaps in existing procedures or for developing new

undertaking a study concerning the right to restitution, compensation and rehabilitation for victims of human rights and fundamental freedoms (E/CN.4/Sub.2/1993/8). Mr. Theo van Boven prepared three versions of the basic principles and guidelines on the right to reparation for victims. The first version is found in document E/CN.4/Sub.2/1993/8 of 2 July 1993, section IX. The second version is found in document E/CN.4/Sub.2/1996/17 of 24 May 1996. The third version is found in document E/CN.4/1997/104 of 16 January 1997. The Commission on Human Rights, in its resolution 1996/35, regarded the proposed draft basic principles elaborated by Mr. Theo van Boven as a useful basis for giving priority to the question of restitution, compensation and rehabilitation; in resolution 1998/43, it requested its Chairman to appoint an independent expert to prepare a revised version of the basic principles and guidelines elaborated by Mr. Theo van Boven with a view to their adoption by the General Assembly. Pursuant to paragraph 2 of resolution 1998/43, the Chairman of the Commission on Human Rights appointed Mr. M. Cherif Bassiouni to perform this task. These Principles were preceded by the Declaration of Basic Principles for Victims of Crime and Abuse of Power, adopted by General Assembly resolution 40/34 on 29 November 1985. Attention is also drawn to the resolution adopted by the Committee of Ministers of the Council of Europe on 28 September 1977, which aimed at harmonizing national laws in the field of compensation for victims of crime, Resolution (77) 27, adopted during its 275 th meeting.

9 Principle 11, UN Principles on the Right to a Remedy, op. cit. (note 8).

10 Principle 21, ibid.

11 Recommendation 13, The Agenda for Peace, UN Doc. A/54/98. 
procedures. Lastly, the International Law Association ("ILA") recently initiated a project on "compensation for the victims of war". ${ }^{12}$ Noting that civilians are left without any remedy if they are killed or wounded or suffer property or other losses, the project aims "to systematically review the law of war and human rights with a view to focusing on the rights of victims of war to compensation". The proposed project has as its goal the preparation and adoption of a Draft Declaration of International Law Principles on Compensation to Victims of War. ${ }^{13}$

Against the background of the above ideas and proposals, the present paper examines the legal ways and means currently available under domestic and international law to victims of violations of IHL to have their primary rights respected. ${ }^{14}$ It explores whether victims have the right to a remedy and the extent to which this right can be enforced, if at all. On the basis of a brief survey of national and international practice, it will be argued that although there is little doubt that victims enjoy rights under IHL, their rights appear to be hardly justiciable and hence difficult to transform into a right to a remedy or reparation.

This paper is restricted to an examination of victims of violations of IHL. While they have a lot in common with victims of other crimes, national and international, as well as with victims of human rights violations, attention has already been devoted to these latter kinds of victims. ${ }^{15}$ There has, however, been little specific consideration of remedies of victims

12 International Law Association, Newsletter, 17 May 2003.

13 This is considered to be a logical sequel to three ILA declarations already adopted, namely on Mass Expulsion (Seoul, 1986), Compensation to Refugees (Cairo, 1992), and Internally Displaced Persons (London, 2000). Underlying all these declarations is the principle that compensation must, under international law, be paid to victims of human rights abuses.

14 This paper is based and enlarges on an earlier article by the author and J. K. Kleffner, "Establishing an individual complaints procedure for violations of international humanitarian law", Yearbook of International Humanitarian Law, Vol. 3, 2000, and on the background reports compiled for the Expert Meeting on Remedies for Victims of Violations of International Humanitarian Law at the Amsterdam Centre for International Law, 9-10 May 2003, and reproduced in Collection of Documents, Amsterdam Centre for International Law, May 2003.

15 On remedies for victims under general international law, see A. Randelzhofer and C. Tomuschat (eds), State Responsibility and the Individual: Reparation in Instances of Grave Violations of Human Rights, Martinus Nijhoff Publishers, The Hague, 1999; C. A. Norgaard, The Position of the Individual in International Law, Copenhagen, 1962. On remedies for victims of human rights violations, see for example D. Shelton, Remedies in International Human Rights Law, Oxford University Press, Oxford, 1999; Netherlands Institute of Human Rights, Seminar on the Right to Restitution, Compensation and Rehabilitation for Victims of Gross Violations of Human Rights and Fundamental Freedoms, Maastricht 11-15 March 1992, SIM Special No. 12. 
of IHL violations. ${ }^{16}$ Furthermore, this paper focuses on the legal right to a remedy. Various obstacles may hamper effective implementation of this right, such as immunities, amnesties, and statutes of limitation, but space limitations preclude consideration of them. For the same reason attention here is centred on the right to compensation and the procedural right to enforce compensation, while recognizing that these are not the only rights victims seek - they have a broad range of needs and seek a variety of remedies, including for example restitution, rehabilitation, and satisfaction.

\section{The notion of "victim"}

The right to a remedy presupposes a victim whose primary rights have been violated. Before elaborating on the issue of remedies, the notion of "victim" under IHL must therefore be clarified. Although the word itself does not appear in the Geneva Conventions or other humanitarian law treaties, ${ }^{17}$ victims obviously are the primary concern of IHL. Such victims may then be defined as those who suffer because they are affected by an armed conflict; they are termed "war victims". This definition potentially refers to an entire population that has been caught up in an armed conflict. However, the occurrence of the armed conflict as such falls outside the scope of IHL, as this law does not deal with the conflict's legality or illegality. Hence war victims have no individual right to peace under IHL. This does not mean that war victims are left without rights, their supreme right being the right to protection..$^{18}$ Indeed, the main purpose of IHL is to protect war victims. ${ }^{19}$

To contend that violation of the right to protection entails a claim to reparation would, however, be absurd, since every member of the population affected by the armed conflict is a victim. The Supreme Court of the Netherlands made

16 The first thorough analysis of the subject is by A. McDonald, "Rights to legal remedies for victims of serious violations of international humanitarian law”, Ph.D. thesis, The Queen's University of Belfast (unpublished).

17 The word "victim" does, however, appear in the title of the two Protocols Additional to the Geneva Conventions of 1949: Protocol Additional to the Geneva Conventions of 12 August 1949, and relating to the Protection of Victims of International Armed Conflicts, 8 June 1977 (hereinafter "Additional Protocol I") and Protocol Additional to the Geneva Conventions of 12 August 1949, and relating to the Protection of Victims of Non-International Armed Conflicts, 8 June 1977 (hereinafter “Additional Protocol II”).

18 Although the different conventions are limited in scope, the Law of Geneva serves to provide protection for all those who, as a consequence of an armed conflict, have fallen into the hands of the adversary. The protection envisaged is against the arbitrary power which one party acquires, in the course of an armed conflict, over persons belonging to the other party.

19 The right to protection entails, among other things, the right to humanitarian assistance. 
clear that for the beneficiaries of the right to protection, notions such as legal remedies and compensation are not workable. In a judgment of 29 November 2002, the Supreme Court decided that rules of IHL do not protect persons against stresses and tensions that are consequences of air strikes as such and do not protect persons with regard to whom the rules and norms have not been violated in concreto. The right to invoke the rules of IHL is therefore confined to those who personally were the victims of violations of IHL. ${ }^{20}$

The wider category of war victims is to be distinguished from what is hopefully a smaller category: victims of violations of IHL, i.e. those who are injured by such violations. This category of victims is defined by the legal restraints placed by IHL on the conduct of war. While the key object of IHL is to protect war victims, it is silent on this second category of victims of IHL violations. The IHL regime focuses solely on persons to be protected against the dangers of war, leaving open the question of action required when protection fails.

The UN Principles on the Right to a Remedy are intended to fill this gap, concentrating on victims of violations of IHL. They define a victim in the following terms: "A person is 'a victim' where, as a result of acts or omissions that constitute a violation of international human rights or humanitarian law norms, that person, individually or collectively, suffered harm, including physical or mental injury, emotional suffering, economic loss, or impairment of that person's fundamental legal rights. ${ }^{21}$

20 Para. 3.2. The Supreme Court dismissed a claim first brought in interlocutory proceedings (kort geding) against the Dutch State to order the latter to immediately stop its (participation in) hostilities against the Federal Republic of Yugoslavia (FRY). From 24 March to 10 June 1999, the Netherlands participated in NATO military operations against the FRY. These operations consisted of air attacks. At the time of the hostilities the claimants were mobilized soldiers in active military service of the FRY. One of the legal questions to be determined by the Supreme Court was whether the air attacks could be qualified as violations of IHL. Arguably such a claim would fall under Article 2(4) of the UN Charter prohibiting the use of force. However, this provision is generally denied direct effect in domestic courts; see for example Amsterdam Court of Appeal (Netherlands), Vierde meervoudige burgerlijke kamer, Dedovic v. Kok et al., judgment of 6 July 2000, para. 5.3.6. Similarly: Gerechtshof Amsterdam, Vierde meervoudige burgerlijke kamer, Dedovic v. Kok et al., judgment of 6 July 2000, para. 5.3.23 (“De regels en normen van dit humanitaire recht strekken ... niet tot de bescherming van personen tegen spanningen of angsten die het gevolg zijn van de luchtacties als zodanig en evenmin tot bescherming van personen jegens wie die regels en normen niet in concreto zijn overtreden. Het komt er dus op aan of ieder van appellanten persoonlijk het slachtoffer is geworden van een gebeurtenis die als schending van humanitair (oorlogs)recht moet worden aangemerkt"). A distinction is sometimes made in this regard between direct victims and indirect victims of IHL (compare Gerechtshof Amsterdam, Vierde meervoudige burgerlijke kamer, Dedovic v. Kok et al., Judgment of 6 July 2000).

21 Principle 8, UN Principles on the Right to a Remedy, op. cit. (note 8): A “victim may also be a dependant or a member of the immediate family or household of the direct victim as well as a person who, in intervening to assist a victim or prevent the occurrence of further violations, has suffered physical, mental, or economic harm". 


\section{The victim's rights}

The victim's right to a remedy and reparation depends in the first place on his/her rights under IHL being violated. The right to a remedy is a secondary right, deriving from a primary substantive right that that has been breached. So if there is no primary right, there can be no secondary right. Recognition of victims of violations of IHL therefore presupposes rights of victims in IHL. Whether individuals possess rights under this regime depends on whether they are the beneficiaries of IHL rules, or, in other words, whether the persons' interests are directly laid down and protected by IHL. ${ }^{22}$

At the outset, the treatment which IHL prescribed to be accorded to protected persons was not presented, nor indeed clearly conceived, as constituting a body of "rights" to which they were entitled. The humanitarian law norms were generally understood as applicable to States vis-à-vis each other and are commonly worded in terms of prohibitions applicable to the parties to a conflict. However, in 1929, the principle of rights was more clearly defined, the word "right" appearing in several provisions of the 1929 Prisoners of War Convention..$^{23}$ And in the 1949 Geneva Conventions the existence of rights conferred on protected persons was explicitly affirmed. ${ }^{24}$ An empirical investigation into these Conventions shows that a number of rules refer explicitly to concepts such as "rights", "entitlements" or "benefits".

In the context of international conflicts, Article 78 of the Third Geneva Convention serves as an example. It gives prisoners of war the right to make known their requests regarding the conditions of captivity to which they are subjected and to complain about such conditions. Similarly, Article 30 of the Fourth Geneva Convention provides all protected persons with the right to file a complaint with the Protecting Powers, the ICRC and the National Red Cross about an infringement of the Convention. These and other provisions create rights of individuals or presuppose the existence of rights. ${ }^{25}$

22 Tomuschat, op. cit. (note 15), p. 7; Norgaard, op. cit. (note 15), p. 48.

23 See for example Arts 42 and 62, Convention relative to the Treatment of Prisoners of War, of 27 July 1929.

24 In particular, Arts 7 and 8 common to the four Geneva Conventions of 12 August 1949.

25 Other examples of such (often indirect) references are contained in Article 7 of the Convention for the Amelioration of the Condition of the Wounded and Sick in Armed Forces in the Field of 12 August 1949 (First Geneva Convention); Articles 6 and 7 of the Convention for the Amelioration of the Condition of Wounded, Sick and Shipwrecked Members of Armed Forces at Sea of 12 August 1949 (Second Geneva Convention ); Articles 7, 14, 84, 105 and 130 of the Convention relative to the Treatment of Prisoners of War of 12 August 1949 (Third Geneva Convention); Articles 5, 7, 8, 27, 38, 80 and 146 of the Convention relative to the Protection of Civilian Persons in Time of War of 12 August 1949 (Fourth Geneva Convention); Articles 44(5), 45(3), 75 and 85(4) of 1977 Additional Protocol I; and Article 6(2) of 1977 Additional Protocol II. 
From case law it may be inferred that the Law of The Hague also endows individuals with rights. In its judgment of 6 July 2000, the Amsterdam District Court (Netherlands) implicitly recognized the notion of individual rights in this branch of law. The appellants sought to invoke alleged violations of Additional Protocol I's Article 52, which sets forth rules on the protection of civilian objects, during NATO's bombing of the FRY as a basis for compensatory claims against members of the Dutch government. The court rejected this claim because, in its view, such violations had not occurred. But, while confining the right to invoke the rules to those who personally were the victims of violations of IHL, the court recognized the possibility of deriving individual rights from IHL rules. ${ }^{26}$

Apart from clear-cut examples of rules that can be conceptualized as "individual humanitarian rights", and with the purposes of IHL in mind, it is possible to identify many more rules that contain elements of individual benefits. For example, the grave breaches provisions could be construed as conferring individual humanitarian rights against acts such as willful killing, torture or inhuman treatment willfully causing great suffering or serious injury to body and health. The same holds true for norms applicable in non-international armed conflicts, such as the prohibition of violence to life, outrages upon personal dignity, and humiliating and degrading treatment, stipulated in Article 3 common to the Geneva Conventions and in Article 4 of Additional Protocol II.

The possible interpretation of other provisions is more doubtful. For example, while Article 15 of the First Geneva Convention ${ }^{27}$ can be construed as conferring individual rights on wounded and sick persons to be searched for and to be collected, it is less clear whether the same provision could also confer a further right to have armistices or a suspension of fire arranged or local arrangements made, whenever circumstances allow, so as to permit their removal, exchange and transport.

26 Gerechtshof Amsterdam, Vierde meervoudige burgerlijke kamer, Dedovic v. Kok et al., Judgment of 6 July 2000 , para. $5 \cdot 3 \cdot 22$.

27 This provision reads: "At all times, and particularly after an engagement, Parties to the conflict shall, without delay, take all possible measures to search for and collect the wounded and sick, to protect them against pillage and ill-treatment, to ensure their adequate care, and to search for the dead and prevent their being despoiled. Whenever circumstances permit, an armistice or a suspension of fire shall be arranged, or local arrangements made, to permit the removal, exchange and transport of the wounded left on the battlefield. Likewise, local arrangements may be concluded between Parties to the conflict for the removal or exchange of wounded and sick from a besieged or encircled area, and for the passage of medical and religious personnel and equipment on their way to that area." 
It may nevertheless be concluded that individuals do have rights under at least some provisions of IHL, a supposition that finds support in the longstanding cross-fertilization of IHL and human rights law. Indeed, the drafting of the Geneva Conventions was already under the influence of the trends, which also resulted in the Universal Declaration of Human Rights. ${ }^{28}$ Additional Protocol II applicable to non-international conflicts likewise underscores in its preamble the close relationship between human rights and IHL: "[r]ecalling (...) that international instruments relating to human rights offer a basic protection to the human person" and "[e]mphasizing the need to ensure a better protection for the victims of those armed conflicts". The Protocol has also copied a number of human rights provisions into its text. ${ }^{29}$ The UN Principles on the Right to a Remedy built upon this apparent close relationship between IHL and human rights law, recognizing in IHL both an undefined set of primary rights and the secondary right to a remedy and reparation outside the human rights regime..$^{30}$ The instrument takes victims of violations of IHL forward in a process of legal empowerment, which started long ago in the human rights sphere.

\section{Right to a remedy}

A question different from, albeit related to, the notion of "rights" is whether these rights can also provide the basis for individual claims brought by victims of violations of them. The position of victims of humanitarian law violations must ultimately be assessed on the basis of their right to claim

28 Y. Sandoz, C. Swinarski, and B. Zimmerman (eds), Commentary on the Additional Protocols of 8 June 1977 to the Geneva Conventions of 12 August 1949, ICRC, Geneva, 1987 (hereinafter "Commentary on the Additional Protocols"), p. 1369.

29 Examples are provided in (parts of) Articles 4 and 6 of Additional Protocol II. See ibid., pp. 1399-1400 and p. 1344.

30 The UN Principles on the Right to a Remedy, op. cit. (note 8) also assume that rights exist under IHL, as a right to a remedy undoubtedly presupposes substantive rights. Principle 1 refers to IHL norms that are contained in inter alia treaties and customary law. The Principles refrain from defining the treaties and customary rules in question, leaving the question which primary rights individuals enjoy under IHL unanswered. In fact, all instruments enumerated by the UN Commission on Human Rights in its resolution adopting the UN Principles are human rights treaties, except arguably the Convention on the Rights of the Child, dealing in Article 39 with child victims of armed conflict (which stipulates: "States Parties shall take all appropriate measures to promote physical and psychological recovery and social reintegration of a child victim of (...) armed conflict”). In his final report the Special Rapporteur explains that the UN Principles were drafted with a view to their being applied "in light of future developments in international law". For this reason, the terms "violations" and "IHL" were not defined, as "their specific content and meaning are likely to evolve over time" (Final Report, op. cit. (note 8), para. 9). The Special Rapporteur may have had in mind here the long-standing cross-fertilization of humanitarian law and human rights law. 
reparation, which includes procedural capacity, i.e. their capacity to go directly themselves to a national or international organ and to claim reparation. As the Diplomatic Conference in 1949 emphasized:

"It is not enough to grant rights to protected persons and to lay responsibilities on the States; protected persons must also be furnished with the support they require to obtain their rights; they would otherwise be helpless from a legal point of view in relation to the Power in whose hands they are." ${ }^{31}$

Support for the assertion that rights provide the basis for claims brought by victims of violations of these rights could arguably be found in Article 3 of the 1907 Hague Convention IV respecting the Laws and Customs of War, which reads:

"a belligerent party which violates the provisions of the said Regulations shall, if the case demands, be liable to pay compensation. It shall be responsible for all acts committed by persons forming part of its armed forces."

Article 91 of Additional Protocol I contains a rule very similar to Article 3 of 1907, ${ }^{32}$ the substance of which is generally accepted as customary international law. ${ }^{33}$ The liability of parties to a conflict to pay compensation for violations of IHL committed by persons forming part of their armed forces could entail an obligation to compensate not only States but also individual victims. ${ }^{34}$ The obligations of States and other warring parties under IHL could thus be construed as being mirrored by victims' rights for which IHL envisages a cause of action if they are violated. Several experts have taken the view that the very purpose of the article has been to confer rights directly on individuals. ${ }^{35}$

31 Final Record of the Diplomatic Conference of Geneva of 1949, Vol. II - A, p. 822. This statement was made in the context of Article 30 of the Fourth Geneva Convention of 1949, entitling protected persons in the territories of the parties to the conflict and in occupied territories to apply, among others, to protecting powers and the ICRC to assist them.

32 The Conference in 1977 accepted Article 91 without much discussion and without dissent, reflecting the general acceptance of the article's contents as established customary law. See expert opinion by F. Kalshoven, "Article 3 of the Convention (IV), respecting the laws and customs of war on land", in H. Fuijta, I. Suzuki, K. Nagano (eds), War and Rights of Individuals, Nippon Hyoron-sha Co, Ltd. Publishers, Tokyo, 1999, p. 37.

33 Commentary on the Additional Protocols, op. cit. (note 28), Commentary on Article 91, p. 1053, para. 3645. Note should also be taken of Articles 51/52/131/148 respectively of the four Geneva Conventions of 1949 which state: "No High Contracting Party shall be allowed to absolve itself or any other High Contracting Party of any liability incurred by itself or by another High Contracting Party in respect of breaches referred to in the preceding Article [enumerating the grave breaches]."

34 Commentary on the Additional Protocols, op. cit. (note 28), pp. 1056-1057, paras 3656-3657.

35 Expert opinions by F. Kalshoven, E. David and C. Greenwood, in War and Rights of Individuals, op. cit. (note 33). 
According to Kalshoven, the word "compensation" instead of, for example, "reparation" should be understood as referring especially to individuals as beneficiaries of the rule. ${ }^{36}$ The UN Principles on the Right to a Remedy are also based on the assumption that violation of IHL gives rise to a right to reparation for victims.

However, while Article 3 of the 1907 Convention, Article 91 of Protocol I and customary law arguably confer rights upon individuals in the event of a violation, including a right to compensation, the question arises whether an individual can assert his/her right against the State or the wrongdoer. Article 3 of the 1907 Convention and Article 91 Protocol I are silent in this regard, leaving it to customary international or domestic law to empower international organs or domestic courts to give effect to that right. A sketchy survey of the available practice shows that primary rights in IHL do not necessarily translate into secondary rights as a consequence of their breach. Victims of violations of IHL can hardly claim compensation through national courts on the basis of Article 3 of the 1907 Hague Convention IV or other provisions. At the international level, more channels are available to victims to claim compensation. But a general remedy does not exist.

\section{Domestic remedies}

Neither humanitarian law as a whole nor any specific article imposes an obligation on States to give direct effect in their national legal systems to the provisions of IHL, in that IHL norms could be invoked by individuals before national courts in the same way as national norms. Where a State does choose to do so, the precise article may be invoked directly before national courts. For other States there is the possibility of integrating the substance, if not the actual articles, of IHL into domestic law. But where neither course is adopted, victims are left empty-handed. This seems to be the more common situation worldwide.

Despite indications to the contrary in the drafting history of Article 3 of the 1907 Hague Convention IV, ${ }^{37}$ national courts have thus far regularly rejected individual claims for compensation based on that provision. ${ }^{38}$ Courts have found most of the IHL rules to be public law norms applying to States only, and not applicable in litigation between injured individuals and the State. For

36 lbid. p. 39. See also F. Kalshoven, "State responsibility for warlike acts of the armed forces: from Article 3 of the Hague Convention IV of 1907 to Article 91 of Additional Protocol I of 1977 and beyond", International and Comparative Law Quarterly, Vol. 40, 1991, pp. 827-858.

37 Kalshoven, op. cit. (note 36), pp. 830-833.

38 lbid., pp. 835-837. 
instance, Japanese courts have continuously dismissed such individual claims in cases relating to violations of IHL during World War II. These cases include the so-called "comfort women" cases. ${ }^{39}$ The plaintiffs, women survivors of military sexual slavery all claiming legal State compensations and apology from the government, argued that individual victims have a right to claim compensation under international customary law and under Article 3 of the Hague Convention applicable at the time of World War II. The Japanese courts denied the existence of such a right both under the said Article 3, and under customary international law.

Likewise, in the case of Leo Handel et al v. Andrija Artukovic, ${ }^{40}$ a US District Court rejected a claim for compensatory and punitive damages based on the 1907 Hague Convention IV and the 1929 Geneva POW Convention. The defendant, the Commissioner of Public Security and Internal Administration and subsequent Minister of the Interior for the Independent State of Croatia, a puppet State of the German Reich, was allegedly responsible for the deprivations of life and property suffered by the Jews in Yugoslavia during World War II. In his official capacity, he oversaw and implemented Croatia's solution to "the Jewish question". As one of the four causes of action, the plaintiffs stated violations of the 1907 Hague Convention and the 1929 Geneva POW Convention. ${ }^{41}$ The decision provides interesting insight into the arguments of national courts to reject such claims. After having set forth the conditions for treaty provisions to be self-executing and to provide a private right of action, ${ }^{42}$ the Court rejected the self-executing character of the invoked provisions. In so doing, it referred among

39 Two out of the ten comfort women claims made against the government of Japan in Japanese courts, seeking an apology and State compensation, were dismissed by the Supreme Court of Japan. The eight other cases have been dismissed by the Lower Court. Other such cases are those of English and Dutch prisoners of war. See the correspondents' reports in the Yearbook of International Humanitarian Law: Hideyuki Kasutani and Seigo Iwamoto, "Japan” in Yearbook of International Humanitarian Law, Vol. 3, 2000, p. 543; Hideyuki Kasutani, “Japan” in Yearbook of International Humanitarian Law, Vol. 2, 1999, pp. 389-390

40 Leo Handel et al. v. Andrija Artukovic on behalf of himself and as representative of the Independent Government of the State of Croatia, US District Court for the Central District of California US 601 f. Supp. 1421 judgment of 31 January 1985, reproduced in M. Sassoli and A. Bouvier (eds), How Does Law Protect in War, ICRC, Geneva, 1999, pp. 713-719.

41 Jurisdiction for the cause of action was based on 28 USC at 1331, which gives the Court jurisdiction over actions "arising under" the "Constitution, laws or treaties" of the United States.

42 The Court held: "The extent to which an international agreement establishes affirmative and judicially enforceable obligations without implementing legislation must be determined in each case by reference to many contextual factors: 1 . the purposes of the treaty and the objectives of its creators, 2 . the existence of domestic procedures and institutions appropriate for direct implementation, 3. the availability and feasibility of alternative enforcement methods, and 4. the immediate and long-range social consequences of self- or non-self-execution.” 
other things to the fact that Article 129 of the Third Geneva Convention that revised and replaced the 1929 Geneva Convention expressly requires implementation through municipal law. According to the Court:

"[a] treaty which provides that signatory States will take measures through their own laws to enforce its provisions evinces an intent that the treaty not be self-executing. (...) As a result, the Geneva Convention does not offer plaintiffs a private right of action...".

The Court then turned to the Hague Convention and held that, although there is no provision in the Hague Convention for implementation into national law, other obstacles would necessitate a rejection of the provision's self-executing power:

"the consequences of implying self-execution compel the conclusion that the treaty is not a source of rights enforceable by an individual litigant in a domestic court. Recognition of a private remedy under the Convention would create insurmountable problems for the legal system that attempted it; would potentially interfere with foreign relations; and would pose serious problems of fairness in enforcement...".

The District Court subsequently addressed the immediate and longrange social consequences of self- or non-self-execution as an additional contextual factor. In its view, self-execution would create a number of practical and political problems that would warrant the rejection of self-execution of the invoked provisions. The relevant passage reads:

"[t]he code of behaviour the Conventions set out could create perhaps hundreds of thousands or millions of lawsuits by the many individuals, including prisoners of war, who might think their rights under the Hague Convention violated in the course of large-scale war. Those lawsuits might go far beyond the capacity of any legal system to resolve at all, much less accurately and fairly; and the courts of a victorious nation might well be less hospitable to such suits against that nation of the members of its armed forces than the courts of a defeated nation might, perforce, have to be. Finally, the prospect of innumerable private suits at the end of a war might be an obstacle to the negotiation of peace and the resumption of normal relations between nations."

This position of US courts towards the self-executing character of IHL was recently confirmed in Hamdi v. Rumsfeld. ${ }^{43}$ Hamdi was seized in 
Afghanistan during military hostilities. Hamdi and amici curiae argued that Article 5 of the Third Geneva Convention of 1949 applies to Hamdi's case and requires an initial formal determination of his status as an enemy belligerent "by a competent tribunal". ${ }^{44}$ In its decision of 8 January 2003, the US Court of Appeals for the Fourth Circuit ruled that the argument failed, inter alia, because:

"the Geneva Convention is not self-executing. (...) Courts will only find a treaty to be self-executing if the document, as a whole, evidences an intent to provide a private right of action. (...) The Geneva Convention evinces no such intent. Certainly there is no explicit provision for enforcement by any form of private petition. And what discussion there is of enforcement focuses entirely on the vindication by diplomatic means of treaty rights inhering in sovereign nations. If two warring parties disagree about what the Convention requires of them, Article 11 instructs them to arrange a 'meeting of their representatives' with the aid of diplomats from other countries, 'with a view to settle the disagreement.' (...) Similarly, Article 132 states that 'any alleged violation of the Convention' is to be resolved by a joint transnational effort 'in a manner to be decided between the interested Parties'. (...) We therefore agree with other courts of appeal that the language in the Geneva Convention is not 'self-executing' and does not 'create private rights of action in the domestic courts of the signatory countries.'."45

The Court assumed that a treaty must provide a private cause of action to be self-executing. However, it is questionable whether this test is correct. It would seem that when a treaty provides individual rights, it should be selfenforcing. And, as we have seen, the Geneva Conventions expressly recognize private rights. Moreover, as Paust pointed out, "the Fourth Circuit panel's reasoning missed the point that a treaty can be partly non-self-executing for one purpose but still be directly operative for another, such as for use defensively or for habeas corpus purposes". ${ }^{46}$

Cases brought before US courts on the basis of universal civil jurisdiction show more potential. Victims of human rights and IHL violations have sought remedies before US courts under the Alien Tort Claims Act (ATCA) and the Torture Victims Protection Act (TVPA). The ATCA, originating

44 lbid. p. 208, Part III, under B.

45 lbid.

46 J. Paust, "Judicial power to determine the status and rights of persons detained without trial”, Harvard International Law Journal, Vol. 44, No. 2, 2003, p. 515. 
from the federal Judiciary Act of 1789, provides the district courts with "original jurisdiction of any civil action by an alien for a tort only, committed in violations of the law of nations or a treaty of the United States". ${ }^{47}$ In Filartiga v. Pena Irala ${ }^{48}$ relatives of a victim of State torture and murder in Paraguay sued the alleged perpetrator for damages in a federal district court in New York. The district court dismissed for lack of jurisdiction, but on appeal the Second Circuit found federal court jurisdiction under the ATCA, allowing US courts to provide foreigners with a remedy for violations of international law wherever they took place. Pursuant to the Filartiga case, several US courts have held that there is universal jurisdiction over certain international crimes, including war crimes, and that this also applies when the conduct complained of occurred outside the United States.

The Filartiga case has been strongly opposed. In Tel-Oren v. Libyan Arab Republic ${ }^{49}$ the US Court of Appeals for the DC Circuit rejected the Filartiga interpretation of the ATCA. The Court found that this statute is merely jurisdictional and does not itself provide plaintiffs with a private cause of action for relief. Victims of a terrorist bombing in Israel sued the various alleged perpetrators, among others alleged agents of Libya, under the ATCA in federal district court in Washington D.C. As judge Bork stated in a concurring opinion: "as a general rule, international law does not provide a private right of action, and an exception to that rule would have to be demonstrated by clear evidence that civilized nations had generally given their assent to the exception". ${ }^{50}$

The cases of Kadic v. Karadzic and Doe I and II v. Karadzic were a turning point in the ATCA proceedings. The plaintiffs in these cases complained that they had been victims of deportation, forced imprisonment, starvation and systematic torture, rape and forced impregnation. The accused, Radovan Karadzic, in his capacity as Bosnian Serb leader, was charged with genocide, war crimes, and torture. In these cases, on 13 October 1995, the US Second Circuit Court of Appeals found that Karadzic's acts, even though they were private, were proscribed by international law and that international law generally, and genocide and war crimes specifically, do not demand State action.

47 Currently codified at 28 U.S.C. $\S 1350$.

48630 F.2d 876 (2d Cir.1980) ILR 77, p. 169.

49726 F.2d, 774 (D.C. Circuit, 1984, Nos. 81-1870, 81-1871.

50 lbid., p. 817. Similarly, see J. M. Rogers, International Law and United States Law, Ashgate Publishing Company, Dartmouth, 1999, pp. 113-123. 
In the subsequent case of Humberto Alvarez-Machain et al. v. USA, the Court of Appeals for the Ninth Circuit rejected the defendants' allegation that the ATCA only confers jurisdictional authority, finding that it also confers substantive legal rights. ${ }^{51}$

In 1992, the US Torture Victim Protection Act codified the holding in the Filartiga case. The Act creates causes of action against individuals who, acting under colour of foreign law, subject a person to torture or extrajudicial killing. ${ }^{52}$ It provides victims of torture, both foreigners and American citizens, with a legal remedy.

Finally, mention should be made of the US Foreign Sovereign Immunities Act of 1976 (FSIA). This Act grants federal district courts concurrent jurisdiction over civil actions against foreign State and related entities. ${ }^{53}$ Some plaintiffs have collected awards under the FSIA, for example in the Letelier ${ }^{54}$ and Siderman ${ }^{55}$ cases.

While recognizing that some cases before Dutch courts as well as US courts' judgments exercising universal civil jurisdiction are promising, the overall conclusion is justified that national courts show, by their reasoning, that their present practice with respect to individual compensatory claims based on rules of international humanitarian law is characterized by judicial timidity and the use of avoidance doctrines. ${ }^{56}$ Insofar as domestic courts have denied individuals rights under IHL, their decisions should be discarded. Not only do the Geneva Conventions expressly recognize primary rights, but IHL also contains the possibility of private rights to compensation, i.e. in Article 3 of the 1907 Hague Convention IV and Article 91 of Protocol I.

A more liberal approach in this regard by the courts in Japan, the United States and elsewhere appears desirable. Whether they will move in that direction is uncertain. In terms of domestic remedies the prospects for a shift under IHL to responsibility vis-à-vis individuals depend largely on national and international legislative developments. At the national level, a State should have in place a legal framework incorporating IHL. An

51 No. 95-55464; No. 95-55768; No. 95-56121. US Court of Appeals for the Ninth Circuit. 107F. 3d. 696, 1996 US App. LEXIS 37014, 24 September 1996, as amended 19 February 1997.

52 G. B. Born, International Civil Litigation in United States Courts: Commentary \& Materials, 3rd ed., Kluwer Law International, The Hague, 1996, pp. 37-39.

53 lbid., p. 35.

54 Letelier v. Chile, 488 F. Supp. 665 (D.D.C.1980).

55 Siderman v. Argentina, 965 F.2d 699 (9th Cir. 1992), cert. Denied, 507 U.S. 1017 (1993).

56 Several commentators have considered national case law denying direct rights of individuals under IHL to be wrong. See Greenwood, op. cit. (note 35), p. 68; David, op. cit. (note 35), pp. 54-55. 
obligation to enact such legislation could arguably be derived from Article 1 common to the 1949 Geneva Conventions, which stipulates that contracting States must ensure respect for those Conventions at all times. A number of humanitarian law treaties, such as the Ottawa Convention on Land Mines, Amended Protocol 2 on Prohibitions and Restrictions on the Use of Mines, Booby Traps and other Devices, and the Second Protocol on Cultural Property explicitly oblige the State to adopt appropriate legislation. ${ }^{57}$ Furthermore, the obligation to implement the humanitarian standards through domestic legislation can be inferred from the State's obligation to prosecute violations thereof. In order to be able to prosecute grave breaches and other serious violations of IHL, a State must have the necessary laws in place. The obligation to prosecute can only be implemented through some kind of criminal law statute. ${ }^{58}$

The UN Principles on the Right to a Remedy may prove an important incentive for domestic legislative activities. These Principles are first and foremost concerned with domestic remedies. Principle 2 reads: "States shall ensure that domestic law is consistent with international legal obligations by (...) [i]ncorporating norms of international human rights and humanitarian law into their domestic law, or otherwise implementing them in their domestic legal system". As the Principles require States to transform IHL into national law, the question of direct effect of IHL rights does not arise. Alternatively, a private right of action before domestic courts could be recognized under international law entitling victims to directly invoke their IHL rights before domestic courts. The UN Principles on the Right to a Remedy provide for this, saying that States must afford appropriate remedies to victims of violations of IHL, including access to justice..$^{59}$

57 Art. 9 of the Convention on the Prohibition of the Use, Stockpiling, Production and Transfer of AntiPersonnel Mines and on their Destruction, of 18 September 1997; Art. 14 of the Protocol on Prohibitions or Restrictions on the Use of Mines, Booby-Traps and Other Devices as amended on 3 May 1996 (Protocol II to the 1980 Convention as amended on 3 May 1996); Arts 15-2 and 16-1 of the Second Protocol to the 1954 Hague Convention for the Protection of Cultural Property in the Event of Armed Conflict, of 26 March 1999.

58 As Meron argued: "As regards the national State of the perpetrators of non-grave breaches, its obligations go further. Given the purposes and objects of the Geneva Conventions and the normative content of their provisions, any State that does not have the necessary laws in place. or is otherwise unwilling to prosecute and punish violators of clauses other than the grave breaches provisions that are significant and have a clear penal character, calls into serious question its good faith compliance with its treaty obligations." T. Meron, “International criminalization of internal atrocities", American Journal of International Law, Vol. 89, 1995, p. 570.

59 Principles 8(d) and 10(a), UN Principles on the Right to a Remedy, op. cit. (note 8). 


\section{International remedies}

At the international level, too, victims of violations of IHL are hardly able to exercise their rights under that law. There is no general international mechanism allowing them to assert those rights. The UN Principles on the Right to a Remedy state that the right to an adequate remedy against a violation of IHL includes "all available international processes in which an individual may have legal standing". ${ }^{60}$ But although the Geneva Conventions and their Additional Protocols contain many provisions for the punishment of individuals who have committed grave breaches, they do not provide for any remedy for the victims of these crimes. As the law now stands, the only compulsory procedure for ascertaining violations is the enquiry procedure established by Article 90 of Protocol I. ${ }^{61}$ However, apart from the fact that as yet the International Fact-Finding Commission has not dealt with any case, the procedures set forth in Article 90 and in the Rules adopted by the Commission do not allow individual victims of violations of IHL to bring cases.

In practice, all existing procedures under IHL are subject to the agreement of the parties to the conflict concerned and none provide individual victims with a general right to a remedy for violations of the law. Without claiming to be exhaustive, I shall deal with a number of examples. ${ }^{62}$

\section{International Committee of the Red Cross}

The ICRC claims to be the primary international body for the protection of war victims. It is broadly mandated to protect and assist war victims and to act as promoter and guardian of IHL. It is specifically empowered "to undertake the tasks incumbent upon it under the Geneva Conventions, to work for the faithful application of international humanitarian law applicable in armed conflicts and to take cognizance of any complaints based on alleged breaches of that law" ${ }^{63}$ Demonstrating how this may work out in practice, a former head of the ICRC delegation in Colombia reports:

60 Principle 12, ibid. This should be without prejudice to any other domestic remedies.

61 The International Fact-Finding Commission is a creation of Article 90 of Additional Protocol I. It was established in 1991, once the conditions set forth in Article 9o(1)(b) were fulfilled.

62 Not examined are the United Nations organs. For the application of humanitarian law by the United Nations, see H-P. Gasser, "Ensuring respect for the Geneva Conventions and Protocols: The role of third States and the United Nations", in H. Fox \& M. A. Meyer (eds), Effecting Compliance, British Institute of International and Comparative Law, London, 1993, pp. 15-49.

63 Statutes of the International Red Cross and Red Crescent Movement, adopted by the International Conference of the Red Cross (1986, amended 1995), Art. 5(2)(c). Text unchanged in Statutes of the ICRC (1998) Art. 4(1)(c). 
"[i]n addition to the hostage cases and complaints registered from persons in detention, the ICRC annually registers over 1,500 individual complaints from victims of breaches of IHL committed by the various actors of the armed conflict. These complaints may concern extrajudicial executions, non-restitution of bodies, and threats against life and property. In many instances, ICRC delegates transmitting such complaints can help to establish authorship of the violations, demand and sometimes obtain reparation, clarify the seriousness of threats and at times obtain the retraction thereof, identify location of graves, and negotiate the restitution of corpses. The ICRC also regularly submits confidential reports on such complaints and reminders of prevailing provisions of IHL to the government, the insurgents, and the autodefensas [which is a rightist paramilitary grouping]". ${ }^{64}$

While the ICRC's entire focus is on seeing that IHL is applied, it has no official implementation procedures at its disposal and its mandate and activities certainly do not provide victims with a right to a remedy. It does not have the means to make enforceable determinations with regard to claims of individuals who allege that they are victims of such violations, nor is that its purpose. Instead, it operates mainly through confidential discussions with governments.

\section{Human rights bodies}

The best prospects seem to exist where human rights law and international humanitarian law overlap. Although the human rights courts are not humanitarian law courts and are not in any respect explicitly related to the field of IHL, they do provide a forum for victims of violations of IHL.

The Inter-American Commission and Court on Human Rights have adopted the most liberal attitude, applying IHL directly in the context of the individual complaints procedure. The Commission stated its view that it should apply IHL because it would enhance its ability to respond to situations of armed conflict. It found that the American Convention on Human Rights, although formally applicable in times of armed conflict, is not designed to regulate situations of war. In particular, the Commission noted

64 P. Gassmann, “Colombia: Persuading belligerents to comply with international norms", in S. Chesterman (ed.), Civilians in War, Lynne Rienner Publishers, London, 2001, p. 90, footnote 16, cited in F. Kalshoven, "The International Humanitarian Fact-Finding Commission established by the First Additional Protocol to the Geneva Conventions", in Collection of Documents, op. cit. (note 14), pp. 9-30. 
that the American Convention does not contain rules governing the means and methods of warfare. ${ }^{65}$

In the so-called Tablada case (1997), ${ }^{66}$ the Commission developed an extensive set of arguments in support of its decision to include humanitarian law in its mandate. In brief, it argued that, although an explicit legal basis was absent, several articles of the American Convention should be read as indirectly mandating it to apply IHL. The finding of the Inter-American Commission that it is competent to apply humanitarian law is not unproblematic. For lack of space, those arguments cannot be examined in detail here. ${ }^{67}$ However, a closer analysis of them shows that it is highly questionable whether the American Convention gives the Commission a legal basis to apply humanitarian law.

It is therefore not surprising that its practice was challenged in the Las Palmeras case that concerned a complaint against Colombia lodged with the Commission on 27 January 1994. The complaint led to the adoption by the Commission of a report on the case on 20 February 1998, in which it confirmed its approach in earlier cases of directly applying IHL. Colombia was held to have violated the right to life in Article 4 of the American Convention and Article 3 common to the Geneva Conventions. After the Commission had submitted the case to the Court, the Colombian government entered five preliminary objections in September 1998. With the second and third preliminary objections, Colombia challenged the competence of the Commission and the Court to hold a State responsible for a violation of the right to life under Article 3 common to the Geneva Conventions. In its judgment of 4 February 2000, ${ }^{68}$ the Court

65 It gave the following example: "[B]oth Common Article 3 [of the Geneva Conventions] and Article 4 of the American Convention protect the right to life and thus, prohibit, inter alia, summary executions in all circumstances. Claims alleging arbitrary deprivations of the right to life attributable to State agents are clearly within the Commission's jurisdiction. But the Commission's ability to resolve claimed violations of this nonderogable right arising out of an armed conflict may not be possible in many cases by reference to Article 4 of the American Convention alone. This is because the American Convention contains no rules that either define or distinguish civilians from combatants and other military targets, much less, specify when a civilian can be lawfully attacked or when civilian casualties are a lawful consequence of military operations." IACHR Report No. 55/97, Case No. 11.137, Argentina, OEA/Ser/L/V/II.97, Doc. 38, October 30, 1997, p. 44, para. 161.

66 lbid.

67 For an analysis of the arguments presented by the Commission, see L. Zegveld, "The Inter-American Commission on Human Rights and international humanitarian law: A comment on the Tablada case" in International Review of the Red Cross, Vol. 324, 1998, pp. 505-511.

68 Caso Las Palmeras, Exepciones Preliminares, Sentencia de 04 de Febrero de 2000, Serie C, No. 66. On this case, see F. Kalshoven, "State sovereignty versus international concern in some recent cases of the InterAmerican Court of Human Rights", in G. Kreijen (ed.), State, Sovereignty, and International Governance, Oxford University Press, Oxford, 2002, pp. 259-280. 
admitted these two objections ${ }^{69}$ and found that it was not competent to apply the Geneva Conventions, while being competent to interpret the Geneva Conventions whenever necessary to interpret a rule of the American Convention. ${ }^{70}$ The Inter-American Court held that:

"[a]lthough the Inter-American Commission has broad faculties as an organ for the promotion and protection of human rights, it can clearly be inferred from the American Convention that the procedure initiated in contentious cases before the Commission, which culminates in an application before the Court, should refer specifically to rights protected by that Convention (cf. Articles 33, 44, 48.1 and 48). Cases in which another Convention, ratified by the State, confers competence on the Inter-American Court or Commission to hear violations of the rights protected by that Convention are excepted from this rule; these include, for example, the Inter-American Convention on Forced Disappearance of Persons." ${ }^{\text {"1 }}$

It remained for the Inter-American Commission and Court to use international humanitarian law as a standard of reference. In the Bamaca Velasquez case against Guatemala (judgment of 25 November 2000), dealing with ill-treatment in detention, the Court found that there had been a violation of Article 1(1) of the American Convention on Human Rights that stipulates the duty to ensure respect for the rights in the American Convention, in relation to Article 3 common to the Geneva Conventions. The Court stated:

"Article 1(1) of the Convention provides that the States Parties undertake 'to ensure' to all persons subject to their jurisdiction the free and full exercise of the rights of the ACHR. (...) The Court considers that it has been proved that, at the time of the facts of this case, an internal conflict was taking place in Guatemala. As has previously been stated, instead of exonerating the State from its obligations to respect and guarantee human rights, this fact obliged it to act in accordance with such obligations. Therefore, and as established in Article 3 common to the Geneva Conventions of August 12, 1949, confronted with an internal armed conflict, the State should grant those persons who are not participating directly in the hostilities or who have been placed hors de combat for whatever reason, humane treatment, without any unfavourable distinctions. 
In particular, IHL prohibits attempts against the life and personal integrity of those mentioned above, at any place and time. (...) Although the Court lacks competence to declare that a State is internationally responsible for the violation of international treaties that do not grant it such competence, it can observe that certain acts or omissions that violate human rights, pursuant to the treaties that the Court does have competence to apply, also violate other international instruments for the protection of the individual, such as the 1949 Geneva Conventions and, in particular, common Article 3. (...) Indeed, there is a similarity between the content of Article 3, common to the 1949 Geneva Conventions, and the provisions of the American Convention and other international instruments regarding non-derogable human rights (such as the right to life and the right not to be submitted to torture or cruel, inhuman or degrading treatment). This Court has already indicated in the Las Palmeras Case (2000), that the relevant provisions of the Geneva Conventions may be taken into consideration as elements for the interpretation of the American Convention." ${ }^{72}$

The Inter-American Court found that there had been a violation of Article 1(1) of the American Convention in relation to common Article 3 of the 1949 Geneva Conventions; it did not find an independent violation of common Article 3 of the 1949 Geneva Conventions.

Even the Court's mere observation as to violation of IHL would be a step too far for the United States. On 12 March 2002, the US government rejected the Inter-American Commission's request of the same date "to take the urgent measures necessary to have the legal status of the detainees at Guantanamo Bay determined by a competent tribunal". ${ }^{73}$ Recognizing that its specific mandate is to secure respect for human rights, the Commission noted that in the past it had "looked to and applied definitional standards and relevant rules of international humanitarian law in interpreting the American Declaration [on the Rights and Duties of Man] and other Inter-American human rights instruments in situations of armed conflicts". The US government maintained that "the Commission does not have the requisite jurisdictional competence to apply international humanitarian law, including the 1949 Geneva Convention on Prisoners of War" and cited the Inter-American Court's judgment in the 
Las Palmeras case. However, the Court's finding in the latter case on the Commission's and Court's competence to apply IHL is limited to a contentious case, which may end up in a binding decision of the Court. The Commission, on the other hand, based its request for precautionary measures on behalf of the Guantanamo Bay detainees on its broad powers under the OAS Charter and the American Declaration. Be this as it may, clearly the US government sees the Inter-American human rights instruments and IHL as two entirely separate bodies of law, and thereby denying the Inter-American Commission the competence to use IHL either for direct application or as a yardstick for interpretation. ${ }^{74}$

The ever-increasing number of States party to the European Convention on Human Rights means that many cases involve issues which call for consideration of IHL. Although the European Court of Human Rights is still reluctant to involve the law of armed conflict explicitly, it appears to use it as a tool for analysis. On several occasions, humanitarian law seems to have served as a source of guidance in the practice of the European Court. ${ }^{75}$

The African Commission on Human and Peoples' Rights has taken a somewhat different, more flexible, approach. It has discerned a close relationship between humanitarian and human rights law and the consequences which violation of the one has on the other, and sees a need for promoting both together. ${ }^{76}$ In its resolution on Sudan, the African Commission recalled

74 On this case, see F. Kalshoven, "Enemy combatants in American hands: Are there limits to the President's discretion?", typescript on file with author, text expected to be published in December 2003.

75 Humanitarian law has been applied in the context of the following ECHR rights: Article 2 (right to life), Article 3 (prohibition of torture/inhuman treatment), Article 8 (right to family life), and Article 1 of Protocol 1 (right to property). The relevant practice may be categorized under the following headings: destruction of property and displacement of the civilian population, detention and treatment of detainees, conduct of military operations and unlawful killings. Humanitarian law has also surfaced in the practice of other human rights bodies. For instance, in an inter-State complaint against Turkey, Cyprus invoked IHL rules before the European Commission on Human Rights (4 EHRR 482 at 552, 553 (1976) Commission Report). However, the European Commission did not examine this point. See on this subject Ch.M. Cerna, "Human rights in armed conflict: Implementation of international humanitarian law norms by regional intergovernmental human rights bodies", in F. Kalshoven \& Y. Sandoz (eds), Implementation of International Humanitarian Law, Martinus Nijhoff Publishers, Dordrecht, 1989, pp. 31-67.

76 From its Resolution on the Promotion and the Respect of International Humanitarian Law and Human and Peoples' Rights, it appears that the African Commission regards both sets of laws as being based on the same principles: "Considering that human rights and IHL have always, even in different situations, aimed at protecting human beings and their fundamental rights...". In Seventh Annual Activity Report of the African Commission on Human and Peoples' Rights, 1993-94, ACHPR/RPTl7th at Annex XI.

In the same resolution, the Commission combines considerations of humanitarian and human rights law in a number of ways. It sees a need for promoting both together: "Emphasizing the importance of propagating the principle of human rights law as well as IHL”, Resolution on Human and Peoples' Rights Education, Ibid., at Annex X. 
that "Sudan is legally bound to comply with international human rights and humanitarian law treaties and has ratified (...) the four Geneva Conventions of 1949". ${ }^{77}$ While there is thus an implication that the African Commission is holding itself up as supervisor of the implementation of IHL instruments, hitherto no individual complaint has, as far as I am aware, been decided directly on the basis of IHL.

In sum, all regional human rights bodies have become adept at examining human rights questions in a humanitarian law context. This practice encouraged Christopher Greenwood, in his Report on International Humanitarian Law presented for the Centennial of the 1899 Hague Peace Conference, to suggest that the lack of implementation mechanisms for humanitarian law may be remedied by human rights instruments. ${ }^{78}$ More specifically, he suggested that "the monitoring mechanisms of human rights conventions could be used in an indirect way to assist in ensuring compliance with the law applicable in internal conflicts". ${ }^{79}$ In contrast to humanitarian law, human rights treaties are commonly equipped with committees, commissions or courts that are competent to receive complaints from individuals, ${ }^{80}$ and which provide victims of human rights, or indeed IHL violations, with a remedy.

77 Resolution on Sudan, Eighth Annual Activity Report of the African Commission on Human and Peoples' Rights, 1994-95, ACHPR/RPT/8th, Annex VII.

78 C. Greenwood, "International humanitarian law" in F. Kalshoven (ed.), The Centennial of the First International Peace Conference: Reports and Conclusions, Kluwer Law International, The Hague, 2000, pp. $240-241$ and 251-252.

$79 \mathrm{lbid}$. at 240 .

80 "Committees" competent to receive complaints of individuals have been set up under the following human rights treaties: 1965 International Convention on the Elimination of All Forms of Racial Discrimination (Committee on the Elimination of Racial Discrimination); First Optional Protocol to the 1966 International Covenant on Civil and Political Rights (Human Rights Committee); 1984 Convention against Torture and other Cruel, Inhuman or Degrading Treatment or Punishment (Committee against Torture); 1990 International Convention on the Protection of the Rights of All Migrant Workers and Members of Their Families (Committee on the Protection of the Rights of All Migrant Workers and Members of Their Families); Optional Protocol to the Convention on the Elimination of Discrimination against Women (Committee on the Elimination of Discrimination against Women), adopted by General Assembly resolution A/54/4 on 6 October 1999 and opened for signature on 10 December 1999 (not yet in force).

"Commissions" and/or "Courts" have been established in Europe (European Court of Human Rights since the entry into force of the 11th Protocol), Africa (African Commission on Human and Peoples' Rights until the entry into force of the Charter adopted on June 1998, and thereafter Commission and Court on Human and Peoples' Rights), the Americas (Inter-American Commission on Human Rights and the Inter-American Court of Human Rights). 


\section{Claims commissions}

In recent years, there has been a proliferation of tribunals and commissions that have been set up as a result of international or internal armed conflicts to provide remedies for claims from victims of violations of IHL. ${ }^{81}$

Two known examples are the United Nations Compensation Commission (UNCC) and the Eritrea-Ethiopia Claims Commission (EECC), whose jurisdictional bases include specific references to violations of IHL..$^{82}$ The UNCC was established in 1991 by the UN Security Council to implement Iraq's liability, "under international law, for any direct loss, damage, including environmental damage and the depletion of natural resources, or injury to foreign Governments, nationals and corporations, as a result of Iraq's unlawful invasion and occupation of Kuwait" in 1990/1991. ${ }^{83}$ The Security Council thus considered this liability to exist not only between States, but also vis-à-vis individuals and corporations. The vast majority of the 2.6 million claims received are from individuals. ${ }^{84}$ The UNCC's decisions recognize the right of individual civilian victims of IHL violations to claim. ${ }^{85}$

The EECC was established in 2000 by the Eritrea-Ethiopia Peace Agreement "to decide through binding arbitration all claims for loss, damage or injury by one Government against the other, and by nationals (including both natural and juridical persons) of one party against the Government of the other party or entities owned or controlled by the other party that are (a) related to the conflict (...), and (b) result from violations of IHL, including the 1949 Geneva Conventions, or other violations of international law". ${ }^{86}$

81 See N. Wühler, "The role of ad hoc claims commissions", in Collection of Documents, op. cit. (note 14), pp. 50-58; K. Oellers-Frahm \& A. Zimmermann (eds), Dispute Settlement in Public International Law: Texts and Materials, 2nd completely revised and updated edition, Max-Planck-Institut für ausländisches öffentliches Recht und Völkerrecht, Heidelberg, 2001; P. Sands, R. Mackenzie \& Y. Shany (eds.), Manual on International Courts and Tribunals, Butterworths, London, 1999.

The use of international claims mechanisms to deal with the consequences of international or internal conflicts is steadily increasing. This trend is expected to continue. Proposals have been submitted, for instance, in relation to Cyprus, Palestine and most recently Iraq.

$\mathbf{8 2}$ Other examples are the mixed arbitral tribunals set up under the rules of peace treaties after the First World War and similar tribunals set up after the Second World War. These tribunals had the purpose of giving compensation to individuals for losses suffered during the wars.

83 SC Resolution 687 (1991) of 8 April 1991, para. 16.

84 Approximately 7,000 claims have been filed by corporations, and around 300 by governments. See the UNCC's website: <www.uncc.ch>.

85 See e.g., Decision No. 7, UN Doc. S/AC.26/1991/7, para. 6.

86 Peace Agreement, Art. 5, para. 1. 
It is estimated that approximately 400,000 claims have been submitted by individuals of each of the two States. On 1 July 2003, the EECC issued its first decisions on claims filed by Ethiopia and Eritrea relating to the treatment of prisoners of war. ${ }^{87}$

Typically, claims commissions provide for restitution of or return into property, or monetary compensation. In a number of programmes the individual claimants have the right to initiate proceedings. The claimants either submit their claims directly to the respective commissions or - in the case of the UNCC and the EECC - to their government, which in turn submits the claims to the respective commission. The reason that in the latter cases the governments file the claims is administrative rather than a legal conclusion that individuals have no rights of their own to compensation. $^{88}$

Arguably, mass claims mechanisms are the most appropriate for victims of mass crimes committed in settings where it is difficult to resolve claims on a case-by-case basis and where usually limited resources are available. ${ }^{89}$ In view of the specific nature of IHL, compensatory measures in particular are likely to be problematic. By individualizing claims of reparation for violations of IHL that occur in the midst of armed conflict and are sometimes committed on a large scale, possibly as part of a plan or policy, the capacities of an international body may be overwhelmed. ${ }^{90}$ The more extensive the violations of humanitarian law and the greater the number of potential complainants, the more likely that body is to be confronted with a breakdown of law and order within the State concerned. In such situations the need for claims commissions will be greatest, as domestic remedies are not effective. These commissions will be better equipped to deal with practical problems such as implementation of monetary compensation to all victims that is proportionate to the gravity of the violation.

87 EECC, Partial Award Prisoners of War, Ethiopia's claim 6 between the Federal Democratic Republic of Ethiopia and the State of Eritrea, The Hague, July 1, 2003; EECC Partial Award Prisoners of War, Eritrea's claim 17 between the State of Eritrea and the Federal Democratic Republic of Ethiopia, The Hague, July $1,2003$.

88 See, for example, Report of the Secretary-General on the Establishment of the UNCC, UN Doc. S/22559, para. 21.

89 N. Wühler, op. cit. (note 81), pp. 56-57.

90 For corresponding considerations with regard to grave human rights violations, see C. Tomuschat, op. cit. (note 15), pp. 1-25. See also Leo Handel v. Andrija Artukovic, US Distr. Cal. (1985), op. cit. (note 40) and accompanying text. 
At the same time, in all mass claims systems the involvement of the individual victims in the procedure is limited. They submit the claims but take no further part in the proceedings unless so requested by the commission in question. There is thus no individualized resolution of a case in a judicial or arbitral process. Another problem is of course that this type of procedures are ad hoc, their establishment being dependent upon political feasibility. It is necessary that victims be allowed to claim the protection of the Geneva Conventions and other IHL instruments, not as a favour, but as a right. In case of violation, international procedures should be available to demand respect for IHL. The prospect of a wholly discretionary response by the international community to the question of setting up a claims commission will not be enough to satisfy the need for remedial effectiveness. Some element of enforceability is required.

\section{International criminal tribunals}

Similar problems are inherent in remedies for victims of war crimes provided by international criminal tribunals. The primary emphasis of such tribunals is on punishment of criminals, and the focus on victims and their remedies is limited. While the prosecutor is expected to represent the interests of the international community, including those of the victims, the prosecutor's concerns do not necessarily match those of the victims.

Nonetheless, some measure of attention is given to victims and their remedies. In its Resolution 827 (1993) of 25 May 1993 adopting the Statute of the International Criminal Tribunal for the former Yugoslavia, the Security Council decided that "the work of the International Tribunal shall be carried out without prejudice to the right of victims to seek, through appropriate means, compensation for damages incurred as a result of violations of international humanitarian law". Both the ICTY and ICTR Statutes and Rules provide for the restitution of property or the proceeds thereof to victims, and in this context a Trial Chamber may determine the rightful owner of the property at issue. Thus there is a mechanism in place which provides a remedy for minor crimes. However, for more serious forms of damage - harm to life or person - there is no remedy under the said Statutes. Indeed, Rule 106 of the Rules of both Tribunals stipulates that victims seeking compensation must apply to a national court or other competent body; in these domestic proceedings the victims may, however, avail themselves of judgments of the ICTY or ICTR. 
The Rules of Procedure and Evidence of the Special Court for Sierra Leone ${ }^{91}$ contain a similar provision. Rule 105 on compensation to victims states:

(a) "The Registrar shall transmit to the competent authorities of the States concerned the judgement finding the accused guilty of a crime which has caused injury to a victim.

(b) Pursuant to the relevant national legislation, a victim or persons claiming through him may bring an action in a national court or other competent body to obtain compensation.

(c) For the purposes of a claim made under sub-rule (b) the judgement of the Special Court shall be final and binding as to the criminal responsibility of the convicted person for such injury."

Under these rules, the victims once again depend on national remedies which, as we have seen, are often lacking. In the absence of a national court with the power and the will to award reparations, victims are left without an important means of recourse. ${ }^{92}$ The UN Principles on the Right to a Remedy aim to fill the domestic gap. Principles 4 and 5 deal with "violations of (...) international humanitarian law that constitute crimes under international law". Read together with the other Principles, this means that States are obliged to afford appropriate remedies to victims of war crimes. Furthermore, Principle 7 provides that statutes of limitations for "pursuing civil claims should not unduly restrict the ability of a victim to pursue a claim against the perpetrator, and should not apply with respect to periods during which no effective remedies exist for violations of (...) international humanitarian law norms".

The International Criminal Court was established with similar goals in mind, i.e. punishment and deterrence. However, concerned by the lack of attention given to victims by the provisions setting up the ICTR and ICTY, ${ }^{93}$

91 For the Statute of the Special Court, see Annex to the Report of the Secretary-General on the Establishment of a Special Court for Sierra Leone, UN Doc. S/2000/915 (2000), as amended on 16 January 2002. See also SC Resolution 1315 (2000).

92 Judge F. Pocar, “The international criminal tribunals", in Collection of Documents, op. cit. (note 14).

93 As the French Minister of Justice pointed out: "We must (...) stop, once and for all, regarding victims merely as witnesses (...) [V]ictims are not simply witnesses whose participation in proceedings should be limited to gathering the information which they are able to provide. They have a separate role to play, and this must be recognised by the International Criminal Court, as is expressly provided for, moreover, by the Rome Statute. A victim's primary status is that of a person who has suffered; he may also have the secondary status of a person who has seen or heard things. The one does not exclude the other, but the injury suffered is enough in itself fully to justify the entitlement of such a person to express his concerns and complaints to the Court.", E. Guigou, Address by the Ministry of Justice at the International Colloquium on “L'Accès des victimes à la Cour pénale internationale" (27 April 1999) (unofficial translation). 
the Rome Statute incorporates more avenues of redress for victims. Article 75 of the Rome Statute of the International Criminal Court obliges the Court to "establish principles relating to reparation to, or in respect of, victims, including restitution, compensation and rehabilitation". Article 79 calls for the establishment of a trust fund for the benefit of victims of crimes within the jurisdiction of the Court, and of the families of such victims, and Article 69 mandates the Court "to protect the safety, physical and psychological well-being, dignity and privacy of victims" and to permit the participation of victims at all "stages of the proceedings determined to be appropriate by the Court". The ICC Statute thus goes well beyond the treatment of victims under the ICTY and ICTR Statutes and Rules, as it gives the victim standing in his or her own right. ${ }^{94}$

\section{Conclusion}

On the basis of these fragmentary considerations, the conclusion is justified that few examples exist where victims are endowed with a right of their own to a remedy for violations of international humanitarian law. While developments at the national level in the Netherlands and in the United States under the Alien Tort Claims Act and the Torture Victims Protection Act are promising, many cases in which individuals have brought claims under Article 3 of the 1907 Hague Convention before national courts have failed because the courts did not recognize that individuals have standing against the State. They regarded the right in that article as one that only States can exercise on behalf of individuals. At the international level, there has been some progress in the means open to victims for the defence of their rights before international bodies, but the practice of international bodies providing remedies to victims of violations of IHL is ad hoc and is not organized. There is no general mechanism that would allow victims to assert their rights under IHL.

94 Jorda and De Hemptinne comment that these advances leave some difficulties unresolved. They draw attention inter alia to the fact that the ICC Statute does not explain how the victim's intervention in the proceedings can be accommodated with the right of the accused to be tried fairly. Also they stress that the Statute does not deal with the difficult issue of settling the right of reparation without compromising the expeditious conduct of trials, as victims of violations of humanitarian law are generally numerous, see C. Jorda and J. de Hemptinne, "The status and role of the victim”, in A. Cassese, P. Gaeta, J.R.W.D. Jones (eds), The Rome Statute of the International Criminal Court: A Commentary, Oxford University Press, Oxford, 2002, pp. 1388-1389. But these are practical issues to which the Court will have to find a solution. 
At the same time, to say that victims have no individual legal standing in IHL would not be a correct description of the actual state of affairs. Although States are still the traditional subjects of IHL, victims have also, in an increasing number of cases, achieved recognition as subjects of IHL. In the years to come, the UN Principles on the Right to a Remedy will undoubtedly lead to greater attention to application of IHL in domestic and international courts, and thus to an injection of IHL norms in the approach to individual remedies. The UN document is a welcome move towards bringing about remedies for victims of violations of IHL. It still has nonbinding status. However, this does not necessarily negate its potential influence, for there are many examples of similar documents exerting influence in litigation. 


\section{Résumé}

\section{Réparation en faveur des victimes selon le droit international humanitaire}

\section{Liesbeth Zegveld}

Le droit international humanitaire garantit la protection et l'assistance des victimes de conflits armés. Cependant, lorsque des personnes deviennent victimes de violations du droit humanitaire, la protection conférée par cette branche du droit cesse de fait. En particulier, $a$ priori elle offre aux victimes de violations graves peu de possibilités d'obtenir réparation, voire aucune.

Le droit international humanitaire diffère nettement sur ce point des tendances en droit international en la matière. Les droits de l'homme, branche de droit analogue mais distincte, définit clairement le droit des victimes d'obtenir réparation en cas de violation des droits fondamentaux. Depuis peu, le Statut de Rome de la Cour pénale internationale autorise la Cour à déterminer dans sa décision l'ampleur du dommage, de la perte ou du préjudice causé aux victimes et à leur accorder réparation. En revanche, le droit humanitaire ne garantit pas expressément aux victimes de violations le droit à un remède juridique.

Cet article examine les moyens juridiques mis à la disposition des victimes de violations du droit international humanitaire par le droit interne et le droit international pour qu'elles fassent respecter leurs droits fondamentaux. Il étudie la question de savoir si les victimes ont droit à un remède et dans quelle mesure elles peuvent faire valoir ce droit. Une brève étude des pratiques nationale et internationale tendrait ainsi à prouver que, s'il n'y a guère de doute sur le fait que les victimes jouissent de droits au titre du droit international humanitaire, ces droits ne semblent toutefois pas justiciable et ne peuvent donc que difficilement donner lieu à un remède. 